\title{
Context and Text: \\ Historicizing Xuanzang and the Da Tang Xiyu Ji
}

GUO WU 伍國

Allegheny College

gwu@allegheny.edu

Abstract: The content of the Da Tang Xiyu ji, or The Great Tang Records of the Western Regions, drew upon Xuanzang's long-term interest in secular things and its compilation was a response to the imperial order of Li Shimin, or Tang Taizong, with the main goal of finding facts about the Western Regions, which Li Shimin was planning to conquer and govern. The book's style and focus inherited traditional Chinese geographical books, local gazetteers and the official history's section on the western borderlands by recording the regions' products and customs, and it passes moral judgments on local people. The book's ethnographical character and Xuanzang's concern with secular affairs and his interest in empirical studies, as well as its goal of providing information to the emperor, are the important aspects that need to be grasped to achieve an in-depth and multifaceted understanding.

Keywords: Tang Taizong, Li Shimin, Xuanzang, Tang Dynasty, Western Regions

DOI: https://dx.doi.org/10.15239/hijbs.03.01.10 
Areat Buddhist philosopher and pilgrim, Xuanzang's 玄壯 time. He 'inherited “scholarly monk's" (xuewen seng 學問僧) academic tradition of emphasizing history and geography', and it is believed that prior to Xuanzang's journey he had read the earlier works on India and the Western Regions by monks of past dynasties such as Faxian 法顯 (338-423), Daoan 道安 (314-385), and Huisheng 惠 生 (d.u.), although except for Monk Faxian’s Foguo ji 佛國記 [An Account of the Buddhist Kingdoms], other works have been missing. ${ }^{1}$ The book's style has been deeply influenced by the Chinese tradition of official historical writing and the genre of local gazetteer. In the official Han shu 漢書 [History of the Former Han Dynasty], there was a section titled the Xiyu zhuan 西域傳 [Record of the Western Regions]. While the author, Ban Gu 班固 (32-92) of the Later Han, adopted the name 'zhuan' 傳 (biography) for this section, it was in fact a geographical survey of the Western Region states. Local gazetteer as a style of historical-geographical writing appeared in the Later Han Dynasty, and it developed greatly during the Wei, Jin, and Southern and Northern Dynasties. There were twelve kinds of local gazetteers that appeared during the Three Kingdoms period, and nine during the Northern and Southern Dynasties. Among them, Chang Qu’s 常璩 (291?-361?) Huayang Guozhi 華陽國志 [Record of the States South of Mount Hua] had the greatest impact. ${ }^{2}$ In this period, the genre of local gazetteer also underwent changing trends: during the Eastern Han, Wei and Jin Dynasties, the authors paid attention to the 'foreign objects'. After the Jin and Song Dynasties, they paid attention to natural landscape. After the Sui and Tang Dynasties, with the re-emergence of the centralized state, the purpose of writing gazetteers became more and more practical. ${ }^{3}$ During the Tang Dynasty, scholars reflected on the past local gazetteers and criticized the Six Dynasties for ignoring the 'useful content of the national economy and the people's livelihood'. ${ }^{4}$ With the founding of the

\footnotetext{
1 Ma, Xuanzang yanjiu, 129-30.

2 Liu, Huayang Guozhi yanjiu, 97-98.

$3 \mathrm{Hu}$, Han Tang jian shixue de fazhan, 160.
} 
centralized multi-ethnic empire, geography, which had been affiliated to the section of historiography in traditional Chinese scholarship, became prominent in the Tang dynasty and was increasingly related to the Tang's rising national power and increasing military expeditions. Xuanzang inherited the extensive record of local economy, geography, customs, and local produces, which had emerged in the gazetteers of the Wei, Jin, and Northern and Southern Dynasties. ${ }^{5}$ In fact, he mentioned the word fangzhi 方志, local gazetteer, in the preface of the Da Tang Xiyu ji 大唐西域記 [Great Tang Records of the Western Regions], in which he critiqued past geographical writings and gazetteers for not 'recording' or not 'reaching' enough of the vast world and various peoples. ${ }^{6}$

The production of the Da Tang Xiyu ji had an explicit official character. Its completion was primarily for satisfying Taizong's desire of understanding the Western Regions and his patronage accounted for the writing. For Taizong, the purpose of ordering such a gazetteer book to be written was 'to obtain the data of the Western Regions for the reference of future military action against the Turks'. ${ }^{7}$ Here, there was not much difference between the purpose of the Da Tang $X i y u j i$ and that of other local gazetteers for they were all related to the Confucian ideal of Great Unity. This symbolic meaning was conveyed very well later on in a Qing scholar's preface dedicated to a county gazetteer: 'A locality might have its gazetteer and then there will be Great Unity'. ${ }^{8}$ To be sure, Xuanzang was not indigenous to the Western Regions while the authors of local gazetteers were usually indigenous scholars to the localities under study. However, the $\mathrm{Da}$ Tang Xiyu ji was also not following the established biographical style used in the Shiji 史記 [Records of the Grand Historian], or the style of the dynastic chronicle in the Han shu 漢書 [History of the Han].

$4 \mathrm{Hu}$, Han Tang jian shixue de fazhan, 176.

5 For the stylish evolution of the Chinese local gazetteers, see Dai, Zhongguo difang zhi jingdu, 27-28.

6 Ji et al., annot., Da Tang Xiyu ji jiaozbu, 1.

7 Lin, Difang wenxian yanjiu yu fenlei, 9.

$8 \mathrm{Li}$ and $\mathrm{Xu}$, Liancheng Xianzhi, 6. 
Instead, it was a miscellaneous account primarily based on the geographical studies of the regions that Xuanzang passed through. The Da Tang Xiyu ji was thus included in the category of the 'Geographical Records of the Western Regions' by Tang Yongtong 湯用䑣 in which he listed eight works by Buddhist monks, and three of them, including the Da Tang Xiyu ji, were explicitly written to observe the order of imperial governments, as indicated by Tang Yongtong.

The conventional wisdom that the Taizong emperor, Li Shimin 李世民 (599-649, r. 626-649), might be a devout Buddhist who not only facilitated the writing of the Da Tang Xiyu ji, but also the massive translations of Buddhist scriptures might be misleading, for Taizong was more a political and military leader than a Buddhist. As Tang Yongtong points out: 'Tang Taizong is not known as a faithful Buddhist', and his patronage of Xuanzang 'was only an embellishment for his governance, and it seems to have political implications'. Tang Yongtong also analyzes in detail the two main reasons why Emperor Taizong did not fully believe in Buddhism: first, he advocated for Confucian literary governance, and thus he 'recognized that Buddhism had no benefit to the world'. Second, Tang Taizong attached more importance to Daoism and he saw himself as the descendent of Laozi, and for this he 'prioritized Daoism over Buddhism'. In addition, Tang Yongtong notes that Tang Taizong's attitude towards various religious beliefs is practical and often contingent upon political needs. ${ }^{10}$

Compared with Buddhism, Taizong's respect for Confucianism seemed to be deeper. According to the records of Zhenguan zhengyao 貞觀政要 [Discourse on the Governance of the Zhenguan Reign], in the first year of Taizong's reign, $626 \mathrm{AD}$, the emperor decreed to establish 'the Expanding Culture on the left side of the main imperial hall' and 'carefully select Confucian scholars nationwide and give them treatment of food on a par with officials with the fifth official rank'. In 627, Taizong 'rejected the Duke of Zhou as the first and foremost sage and began to establish Confucius Temple in the

\footnotetext{
9 Tang, Sui Tang Fojiao shigao, 80-81.

10 Tang, Sui Tang Fojiao shigao, 10-12.
} 
National Academy... with Confucius as the first sage and (Confucius' disciple) Yan Hui as the first teacher.... ${ }^{11}$ Consequently, 'Thousands of Confucian scholars flocked to the Academy with their books'. ${ }^{12}$ If there was a pragmatic political consideration for the attitude toward Buddhism, then it was a non-utilitarian position and effort to establish a pedigree of the orthodox Confucianism. In addition, Taizong's thoughts did have a peaceful and anti-war side. He claimed that 'the weapon is the last resort for it kills people', and 'the weapon and armor are the killing devices of the country'. ${ }^{13}$ This was obviously influenced by the Daode jing 道德經 [Scripture of Dao and De] which says: 'As for weapons - they are instruments of ill omen'. ${ }^{14}$ Taizong's attitude towards Xuanzang, who was four years younger than him, was not so much out of a belief in Buddhism as it was a reward for Xuanzang's talent and perseverance. Arthur Wright even suggests that despite Taizong's patronage of Buddhism, he harbored 'standard anti-Buddhist biases', and Buddhist sources overstated 'both the intimacy of 'Tai'tsung with the monk (i.e. Xuanzang) and the depth of his belated interest in Buddhism'. ${ }^{15}$ To begin with, when Xuanzang left the Tang Empire in 629, the ban of exit was very strict due to the threat of the Turks. Without the imperial endorsement, 'Xuanzang illegally sneaked out of the Yumenguan 玉門關 pass'. ${ }^{16}$ Tang Yongtong admits that Taizong might be 'more inclined to Buddhism than before' because of Xuanzang's influence after his return, but in general, Taizong's favorable treatment of Xuanzang was 'actually because of his appreciation of Xuanzang's talent'. ${ }^{17}$ Returning to China in 645, Xuanzang hoped that Taizong could sponsor a Sanskrit translation team to render Buddhist scriptures, yet the proposal 'was rejected by Taizong'. Not only that, according to Tang Yongtong, Taizong

11 Pian, Zhenguan zhenyao, 229-30.

12 Pian, Zhenguan zhenyao, 230.

13 Pian, Zhenguan zhenyao, 292-93.

14 Henricks, trans., Te-tao Ching, 83.

15 Wright, 'T'ang T'ai-tsung and Buddhism', 254-55.

16 Wang, Sui Tang Wudai shi, 934.

17 Tang, Sui Tang Fojiao shigao, 10-12. 
tried to persuade Xuanzang to 'be secularized to attend to state affairs along with him'. ${ }^{18}$

A late recent biographical study of Xuanzang by the Chinese scholar Fu Xinyi provides more insights in understanding the true relationship between Taizong and Xuanzang: 1) Taizong contributed a preface to Xuanzang's translation and granted his wish of ordaining a large number of Buddhist monks, partially out of Taizong's concern with his own accumulation of virtues; 2) Taizong was much more interested in the information in the pragmatic Da Tang Xiyu $j i$ than the translated Buddhist scriptures; 3 ) it was after reading the Da Tang Xiyu ji that Taizong affirmed Xuanzang's potential of becoming a government official and offered him a position. ${ }^{19}$ These are tenable assertions.

In the interaction between Xuanzang and Taizong, it was Xuanzang who took the initiative. In 644, while on this way back to China and staying in Khotan, Xuanzang wrote a letter of self-introduction and had it delivered to Taizong by a layman messenger from Gaochang. ${ }^{20}$ It is conceivable that it was this letter that attracted Taizong's serious interest in Xuanzang and his journey. In Xu Gaoseng zhuan 續高僧傳 [Sequel to the Biographies for Eminent Monks], the author, Tang monk Daoxuan 道宣 (596-667), provided an alternative account of the writing process of the Da Tang Xiyu ji. First, Daoxuan explained Taizong's lukewarm attitude towards Xuanzang's proposal of scripture translation better by citing Taizong as expressing his concern about the potential lowering of the quality if other monks were invited to join the project. In other words, Taizong did not oppose Xuanzang's single-handed translation yet he doubted the viability of collective translation. According to Daoxuan, Xuanzang's response emphasized the necessity of collaborative translation by citing the precedence of Kumarajiva, and eventually convinced Taizong. Second, Daoxuan never suggested that the writing of the Da Tang Xiyu ji was a task charged to Xuanzang by Taizong.

\footnotetext{
18 Tang, Sui Tang Fojiao shigao, 13.

$19 \mathrm{Fu}$, Xuanzang pingzhuan, 58-61.

20 Wang, 'Xuanzang's Helpers from Turfan', 375.
} 
Instead, Daoxuan's narrative places the writing in the larger context of translation of multiple scriptures, and he went as far as to say that '[When Xuanzang] had a little spare time, [he] presented a twelve-chapter Xiyu zhuan', as if Xuanzang did it as an interlude of his grand translation project. Third, Daoxuan did not suggest that Xuanzang dictated and his assistant, Bianji 讋機 (619-649), recorded because he said Bianji only edited the manuscript and polished it, while he used the word 'luwen' 錄文 to explicitly express the meaning of Zhizheng and other Buddhist assistants' recording Xuanzang's dictation of Dacheng duifa lun 大乘對法論 [Exegesis on the Collection of Mahāyāna Abhidharma; Skt. Mahāyānâbhidharma-samuc-

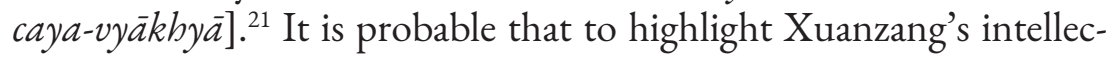
tual autonomy and personal charisma, Daoxuan skirted the fact that Taizong commissioned Xuanzang to write the book, but Xuanzang's passion for writing as suggested by Daoxuan was consistent with his proactive contacting of Taizong in 644. In addition, Daoxuan's narrative about the roles Xuanzang and Bianji each played, namely, Xuanzang was the author while Bianji was the editor, was more accurate.

Contemporary scholar of Buddhism, Fu Xinyi, emphasizes that Xuanzang wrote the Da Tang Xiyu ji purely as an obligation to Taizong to repay his generous patronage and took Taizong as the sole reader, while Xuanzang tried to maintain his own intellectual autonomy by avoiding spending too much time accompanying Taizong and Gaozong 高宗, or Li Zhi 李治 (628-683) as a 'literary jester' in the court. ${ }^{22}$ As a book written with the emperor as his target audience, Xuanzang purposefully traced Chinese history to the legendary cultural heroes such as Fuxi 伏羲, Xuanyuan 軒轅, Yao 堯, and Shun 舜 in the book's preface, saying that 'Our great Tang Dynasty's august power can reach heaven. It took the rules into its hands by taking advantage of the good times... and founded a great enterprise by inheriting the great cultural tradition and rectifying the past wrongs. That was why (the great Tang) can surpass previous kings and dynasties'. ${ }^{23}$

21 Xu Gaoseng zhuan, T no. 2060, 50: 4, 455a19-22.

$22 \mathrm{Fu}$, Xuanzang pingzhuan, 61.

23 Da Tang Xiyu ji jiaozbu, 32. 
In the introductory part, Xuanzang emphasized that the purpose of writing the Da Tang Xiyu ji was to accomplish the goal of 'accommodating and transforming' (buaqia 化洽) the people of the Western Regions: 'If (the great Tang's military merits and literary virtues) were not told, how could we consider transformation'? ${ }^{24}$ Arthur Wright makes an interesting yet sensible speculation here regarding Xuanzang's real and pragmatic purpose: to cultivate in Taizong a more favorable attitude towards Buddhism by 'flattering' this imperial patron. ${ }^{25}$

An important primary source written in the Uygur-Turkic language, however, provides a new glimpse into the real relationship between Xuanzang and the two Tang emperors, Taizong and mainly his son Gaozong. First, in 637, Taizong openly declared that the Daoist master Laozi with the alleged name Li Er 李耳 was his ancestor, and '[Laozi's] status should be placed above the Buddha'. ${ }^{26}$ Thus, Xuanzang needed to rectify this upon his return to China after other monks had tried yet failed, and he also petitioned to Taizong to abolish the decree that punishes the monks and nuns who violated law with secular penal code. ${ }^{27}$ Second, Xuanzang wrote a large number of letters to petition Gaozong begging for the emperor's handwritten text for stone inscriptions in the temple, and then he thanked the emperor for doing it. In another instance, Xuanzang asked the emperor to approve his request of moving his parents' tombs, which he had not swept, to a better place. Xuanzang also never ceased to flatter the Gaozong emperor with nice words and he promised to repay the kindness of the emperor. ${ }^{28}$ To win the trust and secure the support from the two generations of the Tang emperors by advising them was a main strategy used by Xuanzang.

Early Tang Dynasty's political and military conditions indeed required exact knowledge about the Western Regions. As Chen

\footnotetext{
24 Da Tang Xiyu ji jiaozhu, 32.

25 Wright, 'T'ang T'ai-tsung and Buddhism', 255.

26 Barat, ed. and trans., Uygur-Turkic Biography, 74.

27 Barat, ed. and trans., Uygur-Turkic Biography, 78.

28 Barat, ed. and trans., Uygur-Turkic Biography, 16, 40, 120.
} 
Yinke 陳寅恪 (1890-1969) points out: 'The Li-Tang Dynasty was a period when our country had many contacts with foreign peoples, and there were many glorious accomplishments...there were four peoples that had frequent confrontations with China: Turks, Tibetans, Uighurs, and Yunnan'. ${ }^{29}$ As we noted above, Tang Taizong was deeply influenced by both Confucian and Daoist ideologies. Having learned the lesson from the fall of the Sui Dynasty, Taizong was not strongly aggressive, his military actions against Eastern Turks, Gaochang 高昌, Yanqi 焉者, and Qiuci 龜茲 were taken for self-defensive purposes, and the main goal was to secure a sound transportation route for the Tang Empire's trade with the West. The historian Cen Zhongmian 岑仲勉 (1885-1961) was fair-minded when saying that the early Tang's expedition against the Western Regions' kingdoms could not be simply seen as aggression because the main goal of Tang Taizong was not merely for territorial and political dominance, but for the dynasty's 'economy and survival'. ${ }^{30}$

Ji Xianlin 季羡林 (1911-2009) correctly remarks that 'Xuanzang was a very careful observer and he provided particularly detailed account of religious phenomena. Wherever he went and no matter how brief was his stay, he detailed the power relations of the various sects' ${ }^{31}$ However, this was not complete. A close reading of the text of the Da Tang Xiyu ji shows that Xuanzang showed no less interest in secular affairs. Although Xuanzang did not accept Tang Taizong's offer of leaving the monastery life and taking a government position and wrote the book as a duty, the rich content of the Da Tang Xiyu ji itself does show that Xuanzang was by no means apathetic to secular and state affairs during the journey, otherwise it would have been impossible for him to write out all the detailed data. Before he embarked on the writing of the book, Xuanzang must have accumulated enough materials to write this twelve-chapter book, and Xuanzang's

\footnotetext{
29 Chen, Tangdai zhengzhi shi shulun gao, 128.

30 Cen, Sui Tang shi, 96-97.

31 Ji, 'Xuanzang yu Da Tang Xiyu ji', 76. The page number is counted again from one when the preface of Ji Xianlin ends and the main text by Xuanzang starts.
} 
interest in local knowledge was voluntary and genuine, with or without the later imperial order.

The large amount of sources collected for writing the book suggests that Xuanzang's journey was fraught with political and ethnographic concerns, yet he was not alone. He was preceded by official Song Yun 宋雲 (fl. early sixth century) and monk Huisheng, envoys of the Northern Wei to the Western Regions and India to grasp the conditions of the kingdoms en route. These two envoys' notes of the kingdoms, which had been lost and could be partially read in the Luoyang qielan ji 洛陽伽藍記 [An Account of the Buddhist Temples in Luoyang] by Yang Xuanzhi 楊衒之 (fl. 547) of Eastern Wei, were very close to Xuanzang's. For instance, in the record left by Song Yun and Huisheng, the two authors noted:

After travelling to the west of Shanshan 鄯善 for one thousand six hundred and forty $l i$, we arrived at the Zuomo 左末 City. The city had about one hundred households. Its land was dry and short of rainfall and people did not know the use of ox.

They went on to say:

We entered the Bohe 针和 Kingdom in the ninth moon. There were high mountains and deep valleys, and the precarious roads are everywhere. The place where the king resided was a city built by the mountain. Their peoples' clothing was exclusively made of felt. ${ }^{32}$

It is safe to extrapolate that Xuanzang had read the Luoyang qielan ji prior to his travel, and his kingdom-by-kingdom record of the journey was similar to Song Yun and Huisheng's record. What distinguishes Xuanzang's writing was that his record was more detailed and systematic, and his semantic style was freer than Song Yun's, which was the four-character pianwen 駢文 genre popular in the Southern Dynasties.

Xuanzang's observation and record of secular society also resembles the narrative of Faxian in the Foguo ji, a predecessor of the $\mathrm{Da}$

32 Ji, 'Xuanzang yu Da Tang Xiyu ji', 76. 
Tang Xiyu ji completed in the Eastern Jin Dynasty, as well as that of Confucian orthodox histories. For instance, in the Foguo ji, Faxian described the people in Yanqi Kingdom (i.e. Agni Kingdom) as 'not cultivating rituals and righteousness, and treating guests with disrespect', which was close to what Xuanzang said of the same people in the same kingdom about two hundred years later: '(They are) brave yet short of strategy, and fond of waging expeditionary wars'. ${ }^{33}$ Faxian also paid adequate attention to local agriculture, as he recorded the Jiecha Kingdom (Kuci Kingdom in Xuanzang's time) that he passed through as: 'Its land is mountainous and cold and it does not produce surplus grains except wheat'. ${ }^{34}$

To fulfil the goal of providing comprehensive empirical knowledge for understanding and potential governance, the Da Tang Xiyu $j i$ spilled a lot of ink on the geographical, cultural, and economic conditions of the kingdoms that Xuanzang passed by. To illustrate the key objects that attracted Xuanzang's attention and that he wanted to demonstrate to Taizong, I created a chart below (' + ' means there is record about the phenomenon; '-' means there is no mention of it).

\begin{tabular}{|c|c|c|c|c|c|c|c|c|c|}
\hline & 롤 & 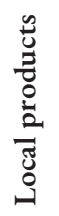 & 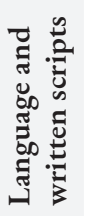 & 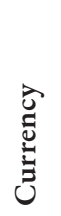 & $\frac{\mathscr{U}}{:=}$ & 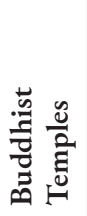 & 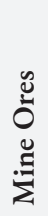 & 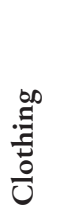 & 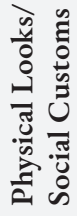 \\
\hline Agni & + & + & + & + & + & + & - & - & + \\
\hline Kuci & + & + & + & + & + & + & + & - & - \\
\hline Bālukā & + & + & + & - & - & + & - & - & - \\
\hline Kasanna & - & - & + & - & - & - & - & + & + \\
\hline Tukhāra & + & - & + & - & + & - & - & + & + \\
\hline Afrasiab & + & + & - & - & - & - & - & - & + \\
\hline Kapiśaya & + & + & + & + & + & + & - & + & + \\
\hline Bārānasi & + & + & - & - & - & + & - & + & + \\
\hline Maghada & + & + & - & - & + & + & - & - & + \\
\hline
\end{tabular}

\footnotetext{
33 Faxian, Foguo ji, 50.

34 Faxian, Foguo ji, 75 .
} 
The chart shows that to serve Xuanzang's purpose of writing, it was less a significant question whether the kingdoms he passed and visited had Buddhist temples, while the territory, area, and terrains that he mentioned the most were also the subjects that were usually placed at the forefront of an official local gazetteer.

The next thing that both local gazetteers and the Da Tang Xiyu $j i$ emphasized were local customs. Xuanzang's appraisal of local customs was not much different from secular and Confucian judgements. For instance, Xuanzang commented on Agni Kingdom by saying: 'the kingdom has no order and discipline, and its law is not implemented'. ${ }^{35} \mathrm{He}$ also paid attention to whether the region he visited had a 'monarch' or not and their political affiliation. When describing Sūyāb, part of the Bālukā Kingdom, Xuanzang emphasized that: 'To the west of Sūyāb there are dozens of lonely cities, each having its chief; although they do not control each other, they are all subjugated by Turkey'. ${ }^{36}$ Here the emphasis on the political connection between these cities and Turkey appealed to the needs of Taizong. For social customs, Xuanzang very often extolled with the words 'crude' ( $z h i$ 質) and 'simple' (chun 淳) and the words and expressions that he used to lash the local people included 'their nature is impulsive and irritable', (they are) 'often treacherous and greedy', 'their nature is timid and looks ugly', and '(their) speech is low and licentious and marriages are in disarray'. Another two phrases, 'the customs are short of rituals and righteousness' (su wu liyi 俗無禮義) and 'the customs are short of rituals and laws' (suwu lifa 俗無禮法), were also often used by Xuanzang to pass judgement on the residents living in the countries that he visited. At the same time, Xuanzang seemed to appreciate the chivalrous spirit among the people of the Mahārāstra kingdom:

(The residents') appearance is imposing, and they have liberal and proud nature. If people give them a favor, they will return it, but if they have grievances, they will straighten them out. If they feel insulted, they will seek revenge by sacrificing their lives, but if someone

35 Faxian, Foguo ji, 48.

36 Faxian, Foguo ji, 72. 
needs their urgent help, they will provide aid without thinking about themselves. ${ }^{37}$

As Bryan Van Norden, a specialist in classical Chinese philosophy, correctly points out: 'An important part of wisdom [in Confucianism] is being able to judge the character of others'. ${ }^{38} \mathrm{I}$ argue that Xuanzang's judgmental comments can be considered as a manifestation of essentially Confucian wisdom, and they served the purpose of fact-finding for the emperor when writing the book. Moreover, the on-site, matter-of-fact recording of his observation and judgement was another sign of Xuanzang's spirit of remaining true to himself.

Xuanzang's judgmental comments on non-Chinese politics and culture based upon the orthodox institutions of the Central Plains were also not alone. In Han shu's account of the Western Regions, there was a comment that goes: 'Each of the Western Region states has its own monarch. Their troops are numerous yet not strong and they are not unified'. ${ }^{39}$ In Wei Yuan's 魏源 (1794-1857) Shengwu ji 聖武記 [An Account of the Sacred Prowess], 'Being without monarch and mutual affiliation' and 'fragmentary government under various tribal chiefs' were the two criteria for defining the Miao and Man 'barbarians' of the southwest, respectively. ${ }^{40}$ When these quintessential Confucian official languages were invoked by a Tang monk, however, the Buddhist observer Xuanzang had wittingly or unwittingly internalized Confucian values and perspectives, as well as the style of orthodox historical writing, to judge the foreign states and societies he witnessed. In the Analects, Confucius was recorded as saying 'only a man of benevolence can like or dislike people', and the commentary of Zhu Xi 朱喜 (1130-1200) added that the judgment must be made with impartial mind and in accordance with the rational principle, $l i$ 理. ${ }^{41}$

\footnotetext{
37 Da Tang Xiyu ji jiaozhu, 891.

38 Van Norden, Introduction to Classical Chinese Philosophy, 40.

39 Ban Gu, Han shu, 3230.

40 Wei Yuan, Shengwu ji, 283.

${ }^{41}$ Zhu Xi, Sishu zhangju jizhu, 69.
} 
Therefore, the book fulfills its dual mission: to become a truly personal account of local conditions based upon first-hand observation and to serve as an official local gazetteer for the information of higher authorities. If the writing of the Da Tang Xiyu ji is regarded as a communicative process between Xuanzang and Taizong, then this context-dependent activity was steered by its purpose: providing the information and assessment that the emperor wanted to hear. Some parts of the book suggest Xuanzang's clear awareness for whom he was writing. In chapter 2 of the Da Tang Xiyu ji, Xuanzang elaborated on India, the destination of his journey. The section titled 'Revenue' was particularly intriguing. Here, Xuanzang stressed that in India:

people have no obligation of providing uncompensated corvée labor... taxes and surcharges are low, and the expenditure is frugal; people are comfortable in what they are doing for the farm is distributed based on the headcount in a household.

In India, he reiterated, 'when the government undertakes construction projects, it will not hire labor to work for free. Workers will be paid according to their workload'. ${ }^{42}$ Born in the Sui Dynasty and deeply immersed in historical books, Xuanzang should know too well that the heavy taxes were one main reason of the Sui's downfall. Prior to writing this account, Xuanzang had admiringly described Taizong to the Indian king Harșavardhana as a benevolent ruler who 'reduced taxes and mitigated punishments', and Tang China was a country with 'surplus revenue' where 'nobody attempts to violate the laws'. ${ }^{43}$ Apparently, Xuanzang was deeply concerned about people's livelihood and he wanted to communicate to Taizong, the receiver of the message, his own endorsement of the policies of land equalization, reduction of taxes, and paid government labor, which he knew Taizong would appreciate. Evidently, Tang Taizong himself also knew very well that it was because 'people could no longer stand the suffer-

\footnotetext{
42 Ji et al., annot., Da Tang Xiyu ji jiaozhu, 68.

43 Sen, 'The Travel Records of Chinese Pilgrims', 30.
} 
ing and then they gathered together to rebel', and thus he said he 'did not dare to employ manpower lightly' and he 'only wants the people to be quieted and stay at ease'. ${ }^{44}$ Xuanzang's elucidation of India's tax and corvée labor system should be aimed at reinforcing Taizong's consciousness of caring for the people by citing a foreign example.

Another part also shows Xuanzang's awareness of his reader. He stayed in Gaochang Kingdom, where he received very warm treatment, for more than one month after his departure from the Tang territory and before he entered Agni. Nevertheless, in the $\mathrm{Da}$ Tang Xiyu ji, Xuanzang skipped his Gaochang experience by merely mentioning it briefly: 'After leaving the old land of Gaochang, the closest kingdom was Agni'. ${ }^{45}$ The reason for Xuanzang's seemingly pragmatic omission of Gaochang was obviously because the Tang government had annihilated Gaochang in 640 and set up the Anxi Frontier Command (Anxi duhufu 安息督護府). Therefore, when Xuanzang was writing his gazetteer in 646 , it was unnecessary for him to depict the conditions of Gaochang, which had been put under Tang government's rule.

There is no doubt that, the primary motivation of Xuanzang's journey to India was pursuing independent research to gain the Buddhist truth. As the Old Tang Dynasty History points out, Xuanzang was not happy with the translated Buddhist scriptures that he read and hoped to find other versions to compare and proofread. Yet the process itself was also identical to the textual criticism and emendation to Confucian classics as done by Confucian classists. Tang Yongtong also notices this aspect while hinting at the difference between scholarly endeavors and religious and ritualistic piety. When discussing Monk Zhu Shixing 朱士行 (203-282) of the Northern Wei who embarked on the trip to search for Buddhist scriptures in $260 \mathrm{AD}$, Tang remarks that 'Zhu's (pursuit) of Buddhist doctrines was more inclined to scholarship, rather than the Buddhist rituals as popular in the Eastern Han dynasty'. ${ }^{46}$ After this statement, Tang

\footnotetext{
44 Pian, Zhenguan zhengyao, 313.

45 Ji et al., annot., Da Tang Xiyu ji jiaozbu, 46.

46 Tang, Han Wei Liangjin Nanbeichao Fojiao shi, 138.
} 
immediately cites the example of Xuanzang, around four hundred years later than Zhu Shixing, to strengthen his argument by saying Zhu Shixing and Xuanzang 'were very close in terms of their merits and contributions, ${ }^{47}$ It is arguable that Tang Yongtong believes that both Zhu and Xuanzang were more scholarly than ritualistic in their approaches to Buddhism.

Xuanzang's intrinsic scholarly and empirical bent was pertinent to his genuine interest in many non-Buddhist life details. Reading the Da Tang Xiyu ji would not convince the reader that Xuanzang could write out all the content merely from his memory. The journey lasted more than ten years and Xuanzang traveled in or at least mentioned about one hundred countries with surprising details. For instance, for the Agni Kingdom alone, the book recorded six local grains: proso millet (mishu 米乘), wheat that matures in the next year (sumai 粟麥), fragrant date (xiangzao 香霜), grape (putao 葡萄), pear $(l i$ 梨), and crab apple (nai 菜). Presumably, no one could write a whole book with so many details without keeping a travel journal and paying close attention to the secular affairs. As I argued earlier, since Xuanzang met with Tang Taizong only after he returned, the initial recording or memorizing of these details en route was highly personal and voluntary and should have been possible through his persistent keeping of travel journal. While the tradition of Buddhist monks' observing and recording natural and social conditions of foreign countries had influenced him, his family tradition and personal background played a crucial role. Born into a 'multi-generation Confucian lineage' and a 'decedent of Chen Shi, a famous minister of the Eastern Han Dynasty', Xuanzang was profoundly influenced by the Confucian cultural tradition prior to his ordainment. He was able to respond to his father at the early age of eight when instructed with the Confucian Classics of Filial Piety. ${ }^{48}$

To conclude, as Ji Xianlin points out, 'the Chinese nation is a nation that deeply loves history, and it is also a nation that deeply loves geography', and 'Chinese monks fully embodied these Chinese

47 Tang, Han Wei Liangjin Nanbeichao Fojiao shi, 138.

48 Zhang and Rui, Da Tang Xiyu ji. 
characteristics: they loved history and they loved geography. ${ }^{49}$ As a scholarly monk equipped with the spirit of positivism and secular concerns, Xuanzang was also an early ethnographer, let alone a great geographic explorer. His travel was both religious and secular and the text of the Da Tang Xiyu ji was the result of several layers of drafting, selecting, and editing. Here we should bear in mind that travel does not only mean the destination, but also 'the self-realization of man' in itself, as well as 'every man's source of philosophical, secular knowledge'. ${ }^{50}$ During this process, Xuanzang subconsciously observed and recorded many details in the social and political life of the West Regions and India, and his ethnographical and judgmental style did not depart much from the local gazetteer tradition of China, which had been entrenched by the time Xuanzang was writing. In terms of the readership, Xuanzang first and foremost gathered the information to fulfill his personal interest, but when the opportunity presented itself, i.e. the emperor wanted to read a completed book for his reference, Xuanzang ornamented the draft with flattering political rhetoric and also wrote in an undertone of advising the emperor.

In this sense, the book as a text blended two segments that match its dual roles: the factual and judgmental part based on the initial observation of Xuanzang himself, and the rhetorical and advising part targeting Taizong. The final work was a result of rewriting from Xuanzang's memory and travel journals and then to the completed book with purposeful embellishments. The political dimension was also integrated because the tailored narrative based on the draft was designed to serve the purpose of future conquest and governance, as in the cases of skipping Gaochang and emphasizing the tax system of India. There is no doubt that Xuanzang was a great, dedicated Buddhist monk, translator, and profound philosopher, yet his deeply ingrained secular sentiments and superb political skills, as reflected in the content of the Da Tang Xiyu ji and its writing, complicates and enriches his image as a well-rounded ancient Chinese intellectual.

49 Ji, 'Xuanzang yu Da Tang Xiyu ji', 123.

50 Fabian, Time and the Other, 6, 8. 
That was the reason why Taizong offered Xuanzang a position in his government two times: he must have seen in Xuanzang the political talent that he needed.

\section{Bibliography}

\section{Primary sources}

Da Tang Xiyu ji 大唐西域記 [Great Tang Record of the Western Regions]. 12 juan. By Xuanzang 玄牀 (602?-664) and Bianji 辡 機 (?-649). Annotated by Zhang Xun 章巽 and Rui Chuanming 荻傳明. Beijing: Zhongguo guoji guangbo chubanshe 中國國際廣 播出版社, 2010.

Daode jing 道德經 [Scripture of Dao and De]. By Lao-tzu 老子.

Reference made to Robert G. Henricks (translated and annotated), Lao-tzu Te-tao Ching 道德經: A New Translation Based on the Recently Discovered Ma-wang-tui Texts. New York: Ballantine Books, 1989.

Foguo ji 佛國記 [An Account of the Buddhist Countries]. 1 juan. By Faxian 法顯 (337-422). Gaoxiong: Foguang chubanshe 佛光出版 社, 1996.

Han shu 漢書 [History of the Han Dynasty]. 120 juan. By Ban Gu 班固 (32-92). Beijing: Zhonghua shuju 中華書局, 1962.

Shengwu ji 聖武記 [An Account of the Sacred Prowess]. 14 juan. By Wei Yuan 魏源 (1794-1857). Beijing: Zhonghua shuju 中華書局, 1984.

Sishu zhangju jizhu 四書章句集注 [Annotated Chapters and Sentences in the Four Books]. 26 juan. Compiled by Zhu Xi 朱 喜 (1130-1200). Beijing: Zhonghua shuju 中華書局, 2011.

$X u$ Gaoseng zhuan 續高僧傳 [Sequel to the Biographies for Eminent Monks], T no. 2060, vol. 50. 30 juan. By Daoxuan 道宣 (596-667). Zhenguan zhengyao 貞觀政要 [Discourse on the Governance of the Zhenguan Reign]. 10 juan. By Wu Jing 吳硯 (670-749). References made to Pian Yuqian 駢宇騫 (translated and annotated), Zhonghua jingdian cangshu: Zhenguan zhengyao 中 華經典藏書: 貞觀政要. Beijing: Zhonghua shuju 中華書局, 2009. 
Secondary sources

Barat, Kahar, ed., trans. The Uygur-Turkic Biography of the SeventhCentury Chinese Buddhist Pilgrim Xuanzang, Ninth and Tenth Chapters. Bloomington: Indiana University Press, 2000.

Cen Zhongmian 岑仲勉. Sui Tang shi 隋唐史 [A History of the SuiTang Dynasties]. Beijing: Shangwu chubanshe 商務出版社, 2010. Chen Yinke 陳寅恪. Tangdai zhengzhi shi shulun gao 唐代政治史 述論稿 [A Draft History of Tang Dynasty's Political History]. Shanghai: Shanghai guji chubanshe 上海古籍出版社, 1980.

Dai Angang 戴鞍鋼. Zhongguo difang zhi jingdu 中國地方誌精讀 [Close Reading of Chinese Local Gazetteers]. Shanghai: Fudan daxue chubanshe 復旦大學出版社, 2008.

Fabian, Johannes. Time and the Other: How Anthropology Makes Its

Object. New York: Columbia University Press, 2002.

$\mathrm{Fu}$ Xinyi 傅新毅. Xuanzang pingzhuan 玄牀評傳 [A Critical Intellectual Biography of Xuanzang]. Nanjing: Nanjing daxue chubanshe 南京大學出版社, 2006.

Hu Baoguo 胡寶國. Han-Tang jian shixue de fazhan 漢唐間史學的 發展 [Development of Chinese Historiography from the Han through the Tang Dynasty]. Beijing: Shangwu chubanshe 商務出 版社, 2003.

Ji Xianlin 季羡林. 'Xuanzang yu Da Tang Xiyu ji 玄牀與《大唐西 域記》[Xuanzang and the Journey to the Western Regions]. In Da Tang Xiyu ji jiaozhu 大唐西域記校注 [Emendation and Annotation to the Journey to the Western Regions], annotated by Ji Xianlin 季羡林, et al., 1-138. Beijing: Zhonghua shuju 中華 書局, 1985.

Ji Xianlin 季羡林, et al., annot. Da Tang Xiyu ji jiaozbu 大唐西域 記校注 [Emendation and Annotation to the Journey to the Western Regions]. Beijing: Zhonghua shuju 中華書局, 1985.

Li Longguan 李龍官, and Xu Shangzhong 徐尚忠. Liancheng Xianzhi 連城縣誌 [Gazetteer of Liancheng County]. Xiamen: Xiamen daxue chubanshe 廈門大學出版社, 2008.

Lin Tianwei 林天蔚. Difang wenxian yanjiu yu fenlei 地方文獻研 究與分類 [Local Source Materials: Study and Classification]. Beijing: Beijing tushuguan chubanshe 北京圖書館出版社, 2006. 
Liu Chonglai 劉重來. Huayang Guozhi yanjiu《華陽國志》研究 [A Study of the History of the Huayang Kingdom]. Chengdu: Bashu shushe 巴蜀書社, 2008.

Ma Pei 馬佩. Xuanzang yanjiu 玄牀研究 [A Study of Xuanzang]. Kaifeng: Henan daxue chubanshe 河南大學出版社, 1995.

Sen, Tansen. 'The Travel Records of Chinese Pilgrims Faxian, Xuanzang, and Yijing: Sources for Cross-Cultural Encounters Between Ancient China and Ancient India'. Educating about Asia 11, no. 3 (Winter 2006): 24-33.

Tang Yongtong 湯用娅. Han Wei Liangjin Nanbeichao Fojiao shi 漢 魏兩晉南北朝佛教史 [A History of Buddhism During the Period of the Han, Wei, Two Jins, and the Southern and Northern Dynasties]. Beijing: Kunlun chubanshe 崦崙出版社, 2006.

—. Sui Tang Fojiao shigao 隋唐佛教史稿 [A Draft History of Buddhism in the Sui-Tang Dynasty]. Beijing: Beijing daxue chubanshe 北京大學出版社, 2012.

Van Norden, Bryan W. Introduction to Classical Chinese Philosophy. Indianapolis/Cambridge: Hackett Publishing Company, Inc., 2011.

Wang, Ding. 'Xuanzang's Helpers from Turfan: Some Notes Based on Medieval Chinese Manuscripts'. Acta Orientalia Academiae Scientiarum Hungaricae 63, no. 3 (September 2010): 363-78. Wang Zhongluo 王仲犖. Sui Tang Wudai shi 隋唐五代史 [A History of the Sui, Tang, and the Five Dynasties]. Shanghai: Shanghai renmin chubanshe 上海人民出版社, 2003.

Wright, Arthur F. 'T'ang T'ai-tsung and Buddhism'. In Perspectives on the Tang, edited by Arthur F. Wright and Denis Twitchet, 239-63. New Haven/London: Yale University Press, 1973. 